\title{
Role of High Tibial Osteotomy in Chronic Posterior Cruciate Ligament and Posterolateral Corner Knee Instability
}

\author{
Salvatore Bisicchia ${ }^{1}$ and Eugenio Savarese ${ }^{2}$ \\ 1University of Rome "Tor Vergata", \\ 2"Tor Vergata", San Carlo Hospital, Potenza, \\ Italy
}

\section{Introduction}

High tibial osteotomy (HTO) has traditionally been performed to correct the mechanical axis of the knee in patients with osteoarthritis (OA) of the medial compartment associated with pain and functional impairment; in these patients the restoration of the alignment was related to the regeneration of the articular cartilage that seemed apparently normal (Fujisawa et al., 1979; Odenbring et al., 1992). Recently, HTO has also become very popular is association with cartilage techniques and meniscal grafts (Noyes et al., 2004). In the past chronic knee instability and varus thrust have been considered a contraindication for HTO (Coventry et al., 1993; Naudie et al., 1999), but nowadays, chronic instability is an indication for HTO, because allows to correct both the coronal and the sagittal alignment, improving the function of an unstable knee. Soft tissue techniques alone, without correction of the alignment, often give poor results because a bone deformity overstresses them (Christel, 2003; Goradia \& Van Allen, 2002; Insall et al., 1984; Neyret et al., 1993). Soft tissue destruction causes a decrease in neuromuscular joint control, which in time can worsen the malalignment (Lephart et al., 1998). Reconstruction of the Posterior Cruciate Ligament (PCL), without repair or reconstruction of the Posterolateral Corner (PLC), often gives poor results (Christel, 2003; Krudwig et al., 2002; LaPrade \& Wentorf, 2002; Noyes et al., 2005; Strobel et al., 2000. Some Authors (Badhe \& Forster, 2002; Coventry et al., 1993; Hernigou et al., 1987; Insall et al., 1984; Nagel et al., 1996; Naudie et al. 1999) have reported satisfying results after HTO in monocompartimental knee OA and varus alignment, whereas there are few studies about the results of HTO in the unstable knee $[9,17,18]$. Recent papers suggest to perform this procedure before soft tissue reconstruction for the treatment of a PCL/PLC deficient knee associated with varus malalignment, to improve function and stability (Badhe \& Forster, 2002; Fowler et al., 1994; Goradia \& Van Allen, 2002). HTO is also useful in the treatment of an Anterior Cruciate Ligament (ACL) lesion associated with a varus of the knee (Dejour \& Bonnin, 1994; Dejour et al., 1994; Fowler et al., 1994; Lattermann \& Jakob, 1996; Lerat et al., 1993; Neuschwander et al., 1993; Noyes et al., 1993, 1996, 2000).

\section{Anatomy}

The tibia is a large bone transmitting, from the knee to the ankle, most of the stress of walking. It is surrounded by three compartments of muscles: the antero-lateral, the lateral 
and the posterior. The medial surface of the tibia is not covered by muscles providing an easier access to the bone (Hoppenfeld et al., 2003). The proximal anteromedial tibial cortex, viewed in a cross section, has an oblique or triangular shape, and it forms an angle of $45^{\circ} \pm 6^{\circ}$ with the posterior margin of the tibia; whereas the lateral tibial cortex is nearly perpendicular to the posterior margin of the tibia (Noyes et al, 2005).

The PCL originates from the lateral aspect of the medial condyle and it inserts on the posterior edge of the tibial plateau. It has 2 boundles, the antero-lateral and the posteromedial (Ahmad et al., 2003; Amis et al., 2006; Takahashi et al., 2006).

PLC consists of three layers (Seebacher et al., 1982). The external layer is formed by the biceps femoris and the ileo-tibial tract. The middle layer is formed by the quadriceps retinaculum and the patello-femoral ligaments. The internal layer consists of a superficial lamina, formed by the lateral collateral ligament (LCL) and the fabello-fibular ligament, and a deep lamina, formed by the popliteo-fibular ligament, the arcuate ligament and the popliteus muscle with its tendon. The two laminae of the internal layer are the most important stabilizers of the PLC.

\section{Biomechanics}

There are three geometric variables to consider in the correction of a deformity (Paley, 1992):

1. Center of Rotation of Angulation (CORA): is the intersection between the proximal mechanical axis (PMA) with the distal mechanical axis (DMA). It is not under surgeon's control because it is related to the morphology of the deformity.

2. Angulation Correction Axis (ACA): is the axis around which the deformity is corrected. It is partially under the control of the surgeon.

3. Level of osteotomy: is totally under surgeon's control.

Given these geometric variables, there are three rules for osteotomies (Paley, 1992):

1. If the level of osteotomy and ACA pass for CORA, the re-alignment takes place without translation.

2. If ACA passes for CORA but the osteotomy is at a different level, the re-alignment takes place with angulation and translation at the osteotomy site.

3. If osteotomy and ACA are above or under CORA, the re-alignment takes place with translation.

ACA and CORA have to be as close as possible to avoid a secondary deformity with translation after the osteotomy is performed. In HTO, ACA and CORA are very close to each other, for this reason only the angular deformity will be corrected after surgery.

Patients with a varus of the knee and posterolateral instability often present the so-called "hyperextension varus thrust gait": during the gait cycle the knee goes into varus and hyperextension, the medial compartment narrows and the lateral compartment enlarges. In chronic lesions, posterolateral structures become overused with a further decrease in function. This phenomenon is increased during gait because all the weight bears on a limb (Chang et al., 2004; Miller et al., 2002; Noyes et al., 2006) (Fig. 1). 


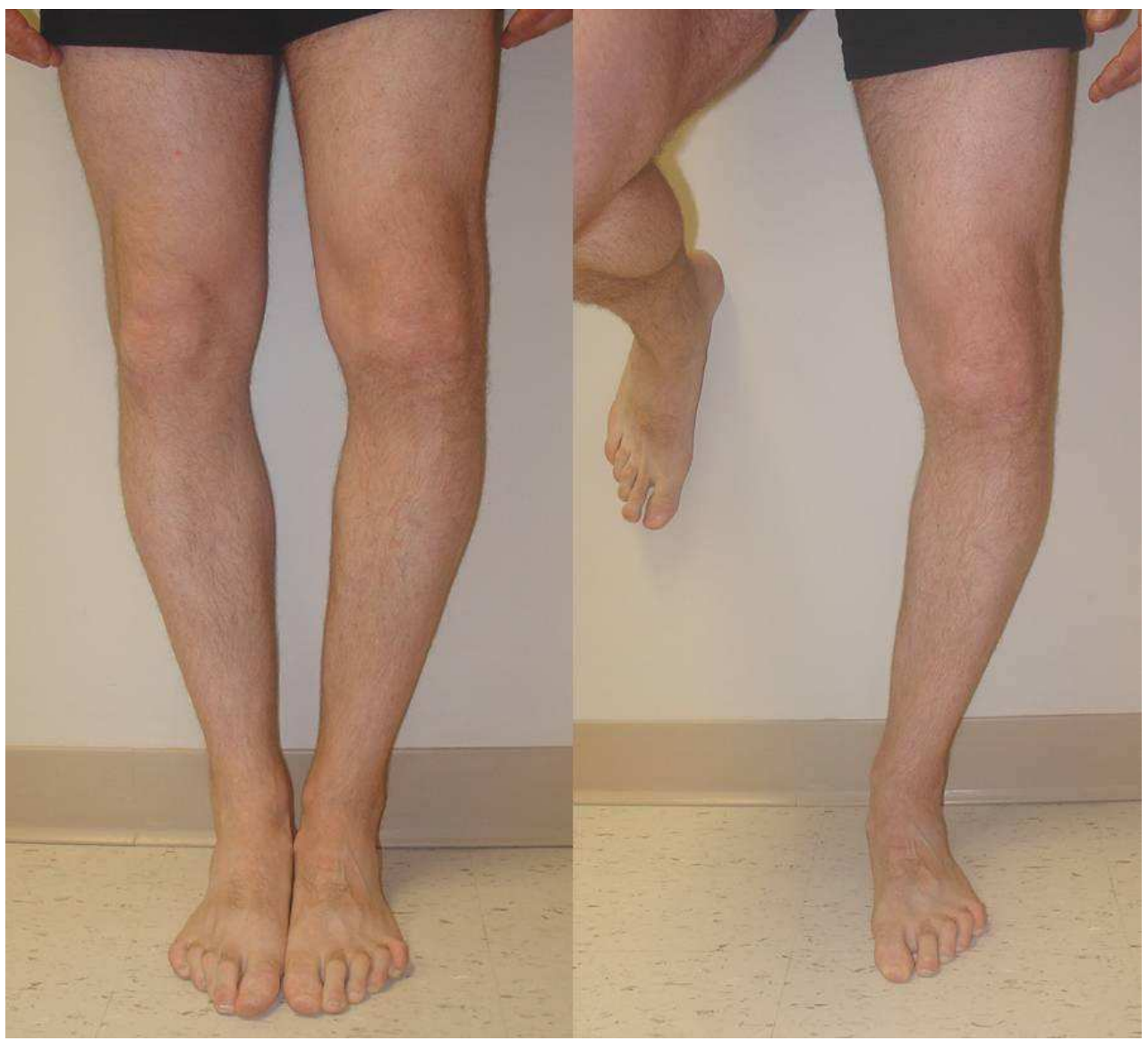

Fig. 1. One foot standing increases hyperextension varus thrust.

\subsection{Effects of a chronic PCL/PLC lesion}

An isolated chronic PCL lesion causes the tibia to translate posteriorly and to rotate externally about the femur. During all the different phases of the gait cycle the knee with a PCL lesion hyperextends, if compared with a normal knee (Noyes et al., 1996; Miller et al, 2002):

- $\quad$ Heel strike with PCL: $1.3^{\circ} \pm 1.6^{\circ}$ of knee flexion

- Heel strike without PCL $-5.6^{\circ} \pm 2.8$ of relative knee flexion (hyperextension)

- $\quad$ Midstance with PCL: $14.9^{\circ} \pm 5^{\circ}$ of knee flexion

- Midstance without PCL: $6.2^{\circ} \pm 10.9^{\circ}$ of knee flexion

- Off Toe with PCL: $6.6^{\circ} \pm 4^{\circ}$ of knee flexion

- Off Toe without PCL: $-7.3^{\circ} \pm 4.4^{\circ}$ of relative knee flexion (hyperextension)

A chronic PCL lesion can have effects on osteo-cartilagineous structures and on soft tissues of the knee. An osteoarthritic degeneration of the medial compartment of the knee is 
possible because of the aforementioned biomechanical changes and a quantitative reduction of PCL mechanoceptors (Safran et al., 1999). After a PCL lesion, the pressure increases of about $30 \%$ in the medial compartment of the knee (LaPrade \& Wentorf, 2002; Lephart et al., 1998). Osteoarthritic changes take place even in the patello-femoral joint, due to an increase in pressure of about 16\% (Ramaniraka et al., 2005; Skyhar et al, 1993), mainly on the lateral facet (because of an internal femoral rotation depending on external tibial rotation), and on the inferior pole (because the posterior tibial translation increases the tension along the patellar tendon: this increases patellar flexion (Kumagai et al., 2002; Li et al., 2002). Soft tissue effects occur mainly on ACL, which presents a decrease in number, diameter and density of collagen fibers (Ochi et al., 1999) and on PLC. Indeed, forces on PLC increase from $34 \pm 25 \mathrm{~N}$ with PCL to $63 \pm 24 \mathrm{~N}$ without PCL at $30^{\circ}$ of knee flexion and from $38 \pm 46 \mathrm{~N}$ with PCL to $86 \pm 53 \mathrm{~N}$ without PCL at $90^{\circ}$ of knee flexion (Hoher et al., 1998).

The effects of a PCL lesion are more evident when a PLC lesion is also present. This is not rare, in $60 \%$ of cases PCL and PLC lesions are associated [46]. The final result is a chronic posterolateral instability, defined as triple varus (Noyes \& Simon, 1994) (Fig. 2). The first varus is osseous, lateral compartment enlargement due to LCL deficiency represents the second varus, the third varus is associated to hyperextension and it is due to PLC deficiency.

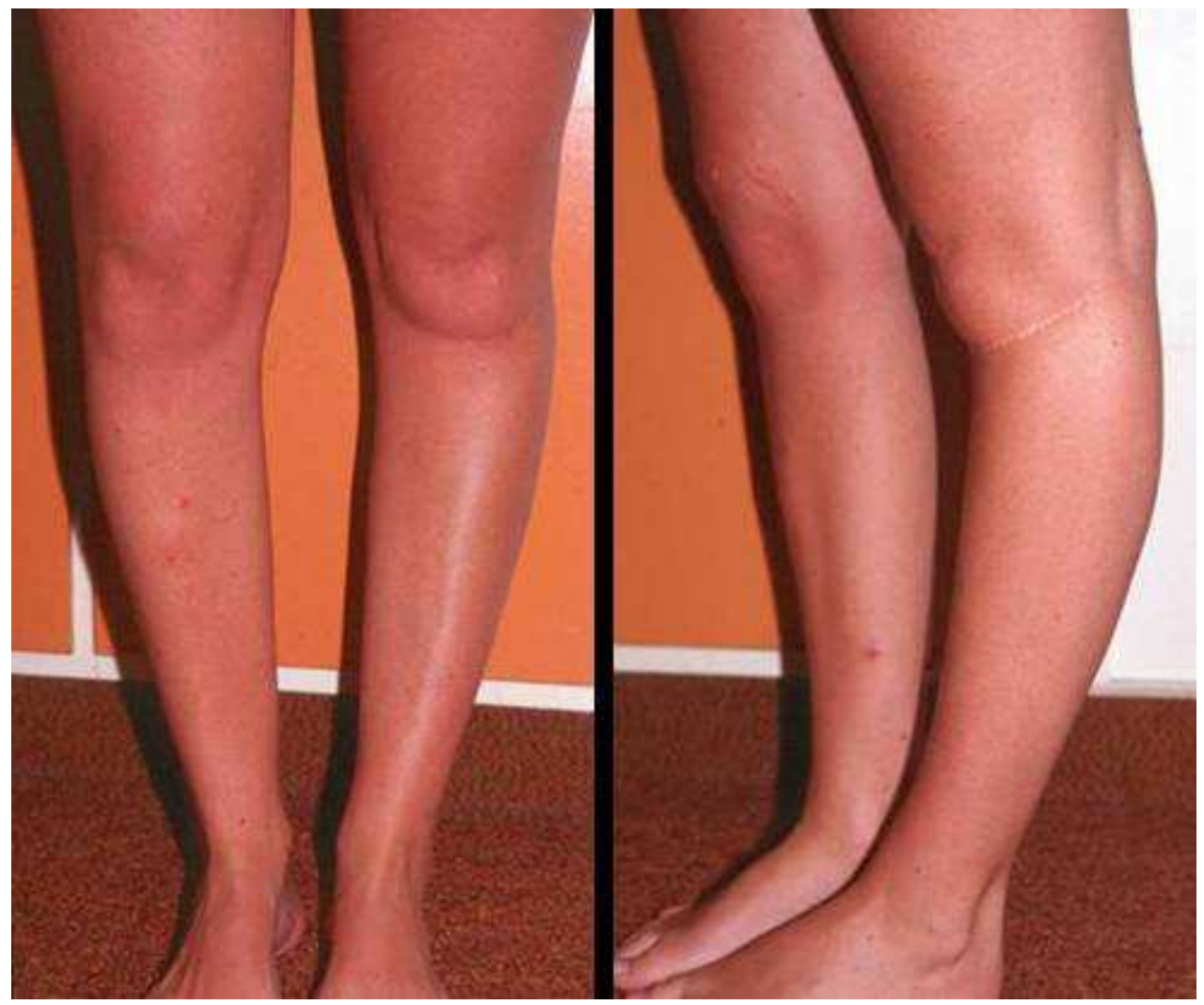

Fig. 2. Posterolateral chronic instability 


\subsection{Observations about posterior tibial slope}

In the normal knee the medial posterior tibial slope is $9^{\circ}-11^{\circ}$ and the lateral posterior tibial slope is $6^{\circ}-11^{\circ}$ however, because there are 5 radiographic techniques described to evaluate its amount (see the Imaging section for more explanations), a wide range of values is reported (Brazier et al., 1996; Chiu et al., 2000; Dejour \& Bonnin, 1994; Genin et al., 1993; Insall , 1993; Lecuire et al, 1980; Matsuda et al., 1999; Paley et al., 1994). The sagittal plane of the knee has often been ignored, however its changes affect biomechanics and joint stability. In fact, with an HTO it is possible to modify both the coronal and the sagittal planes, causing an anterior or posterior translation of the tibia about the femur. This has determined a great increase of osteotomies in the last years for the treatment of chronic knee instability. The proximal anteromedial tibial cortex, viewed in a cross section, has an oblique or triangular shape and it forms and angle of $45^{\circ} \pm 6^{\circ}$ with the posterior margin of the tibia; whereas the lateral tibial cortex is nearly perpendicular to the posterior margin of the tibia. Because of these anatomical features a medial opening wedge HTO increases the tibial slope only if the anteromedial gap is equal to the posteromedial gap, whereas the slope does not change if the anteromedial gap is smaller than the posteromedial gap (Noyes et al., 2005). A lateral closing wedge osteotomy causes a small decrease in posterior tibial slope, a posterior translation of the tibia and stabilizes a knee with anterior instability (Amendola et al., 1989; Boileau \& Neyret, 1991; Hohmann et al., 2006; Lerat et al., 1993; Levigne \& Bonnin, 1991) (Fig. 3). Whereas a medial opening wedge HTO increases the posterior tibial slope, causes an anterior translation of the tibia and stabilizes a knee with posterior instability (Dejour \& Bonnin, 1994; Giffin et al., 2007) (Fig. 4). Moreover, HTO preserves the proximal tibio-fibular joint, does not change the length of the posterolateral structures and prevents proximal migration of the fibula that could increase posterolateral instability.

Usually HTO are stabilized with plates: an anteromedial plate increases the slope, a posteromedial plate tends not to modify the posterior tibial slope [60] (Fig. 5). Furthermore, if the anteromedial gap is the half of the posteromedial gap, the tibial slope does not change. For each increase of $1 \mathrm{~mm}$ in the anterior gap, there is an increase of $2^{\circ}$ in the posterior tibial slope (Noyes et al., 2005), and for every $10^{\circ}$ of varus correction, the posterior tibial slope increases on the average of $2.7^{\circ}$ and the tibia translates anteriorly of about $6 \mathrm{~mm}$ (Bonnin, 1990; Marti et al., 2004). Several authors reported, after HTO, an increase in posterior tibial slope, with an anterior translation of the tibia (Giffin et al., 2004; Naudie et al., 1994) and an decrease of forces on PCL: from $34 \pm 14 \mathrm{~N}$ to $19 \pm 15 \mathrm{~N}$ with the knee flexed at $30^{\circ}$ and from $36 \pm 29 \mathrm{~N}$ to $22 \pm 11 \mathrm{~N}$ with the knee flexed at $90^{\circ}$ (Giffin et al., 2004). This is a further demonstration that an increase in posterior tibial slope decreases stress forces on posterior structures.

Dome osteotomy (Maquet, 1976) is associated with an increase in posterior tibial slope (Cullù et al., 2005; Nakamura et al., 2001), whereas an opening wedge HTO with emicallotaxis, has little influence on tibial slope (Nakamura et al., 2001). An increase in posterior tibial slope causes a change in the pressure on the articular tibial cartilage: the pressure increases in the anterior portion and decreases in the posterior portion. If the tibia translates anteriorly, the pressure on posterior articular cartilage should increase; however, between $120^{\circ}$ of knee flexion and full extension, femoral condyles roll anteriorly on the tibia, shifting anteriorly the contact point (Agneskirchner et al., 2004). 


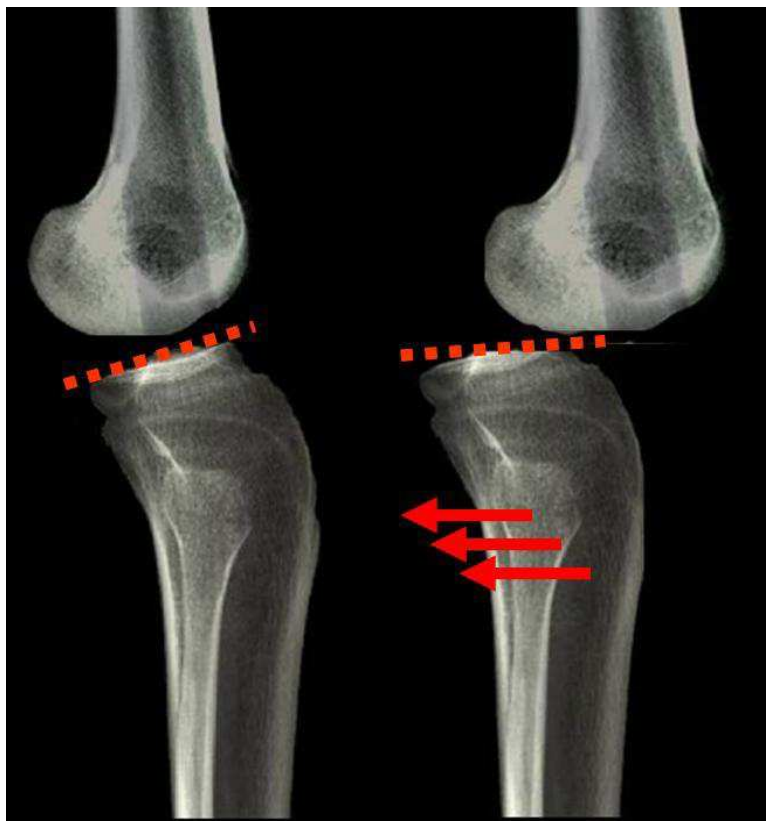

Fig. 3. A closing wedge HTO causes a decrease in posterior tibial slope and a posterior translation of the tibia, it stabilizes a knee with anterior instability.

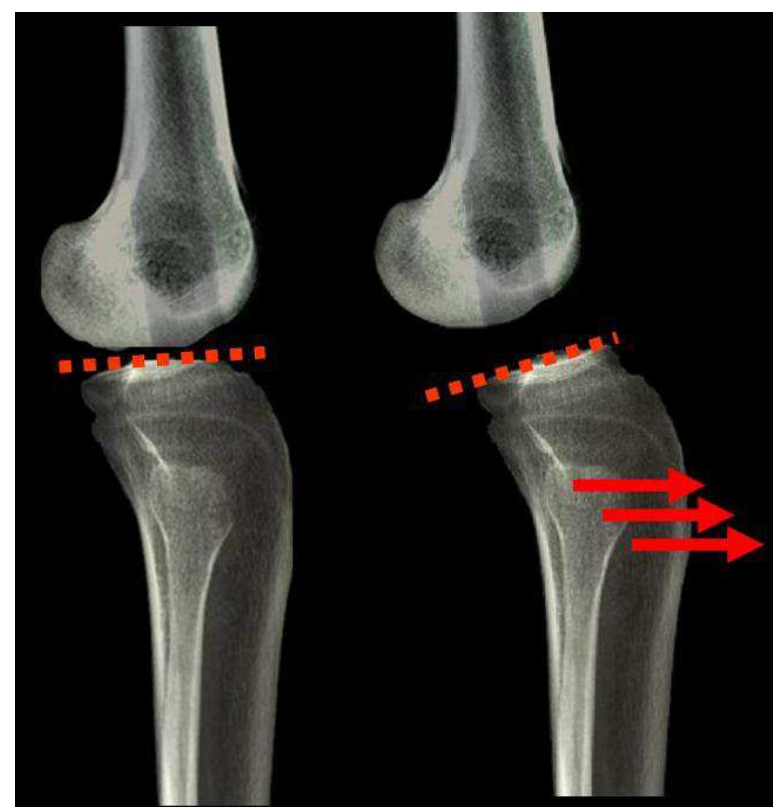

Fig. 4. A opening wedge HTO causes an increase in posterior tibial slope and an anterior translation of the tibia, it stabilizes a knee with posterior instability. 


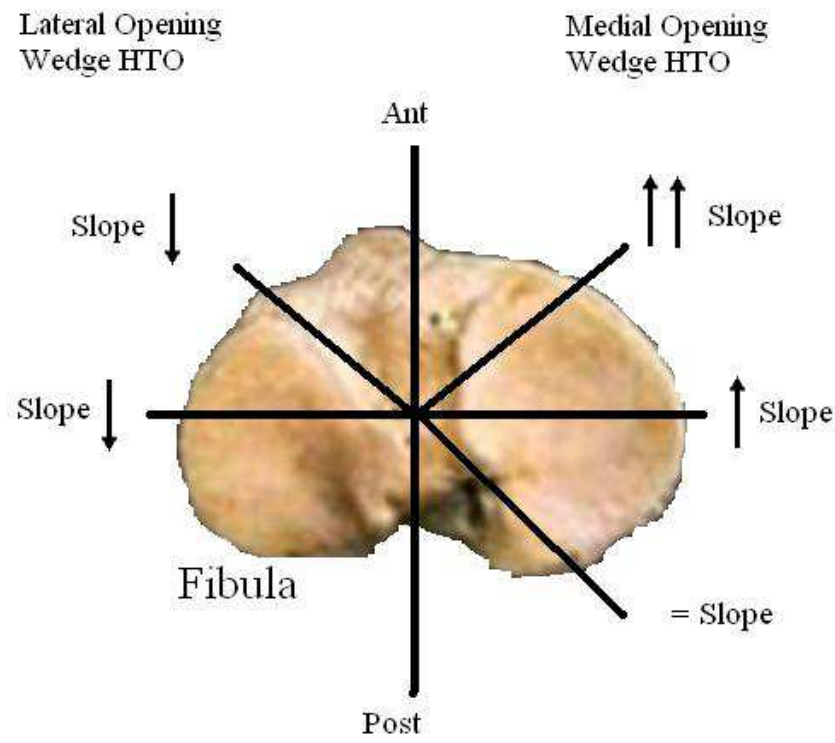

Fig. 5. Relationship between tibial slope and kind and site of osteotomy.

\section{History and physical examination}

Complete history and physical examination are mandatory in the evaluation of all patients, but in a patient with a PCL/PLC lesion, associated with a varus malalignment, they have a particular value, in fact clinical tests for the diagnosis of PCL and PLC lesions have low sensitivity and, in some cases, also low specificity, for these reasons we advise the clinician to perform all the tests described to rule out such lesions.

Because PCL and PLC lesions are associated in 60\% of the cases (Fanelli \& Edson, 1995), if a PCL lesion is suspected or detected, the physician should look for a PLC lesion. Patients with a PCL lesion usually complain about non specific symptoms, the mechanism of injury usually reported is a posterior force applied to the tibia with the knee in flexion (football players or a fall on the flexed knee), and hyperextension or hyperflexion with or without a posteriorly directed force applied to the tibia (Petrigliano \& McAllister, 2006). After an acute PLC lesion, patients usually refer a blow to the anteromedial aspect of the knee, contact or noncontact hyperextension and a varus noncontact force. About $15 \%$ of PLC lesions are associated to a common peroneal nerve injury, it is important to ask the patient about numbness, tingling or muscle weakness, especially in ankle dorsiflexion or great toe extension (LaPrade \& Terry, 1997). Because of the biomechanical changes in PLC after a PCL lesion (see the Biomechanics section), patients with a chronic PLC lesion usually do not refer either a specific trauma or a PCL lesion that might have occurred several years before. Chronic lesion should be suspected during physical examination, and gait analysis is useful in detecting them, so we believe that it should be systematically performed.

During physical examination it is important to identify all the factors involved in posterolateral chronic instability, because they are all related to the surgical outcome. 
- Gait is the first factor to analyze. Patients with posterolateral instability often present the so-called "hyperextension varus thrust gait" (Fig. 1) (see the Biomechanics section). Gait analysis is important to detect PLC associated lesions because, in some cases, patients with hyperextension varus thrust have poorer results than patients with normal gait (Chang et al., 2004; Miller et al., 2002; Noyes et al., 1996).

Many tests are described for the evaluation of PCL and PLC.

- Posterior Sag Sign (Barton et al., 1984; Mayo Robson, 1903) has 79\% sensitivity and $100 \%$ specificity (Rubinstein et al., 1994). The patient lies in the supine position with both knees and hip at $90^{\circ}$ of flexion while the examiner holds the heels of the patient and compares side by side the posterior translation of the tibia from a lateral view.

- Posterior Drawer Test (Paessler \& Michel, 1992; Strobel et al., 1990) has 90\% sensitivity and $99 \%$ specificity (Rubinstein et al., 1994). The patient lies in the supine position, with the knee at $90^{\circ}$ of flexion, the examiner sits on the foot of the patient and applies a posterior force on the anterior tibial shaft comparing side by side the posterior tibial translation.

- Quadriceps contraction (Daniel et al., 1988) has 54\% sensitivity and 97\% specificity (Rubinstein et al., 1994). The patient lies in the supine position with the knee in the drawer position and is asked to slide the foot down the table, if a PCL lesion is present the tibia translates anteriorly more than $2 \mathrm{~mm}$ during quadriceps contraction.

- Dial Test, performed in prone and supine position (Loomer, 1991; Veltri \& Warren, 1994). The patient lies in the supine position with both thighs supported by an holder or allowed to hang off the end of the examining table and stabilized by an assistant at $30^{\circ}$ of knee flexion. The examiner externally rotates the lower legs and compares the tibial tuberosity external rotation side by side. In the prone position an assistant is not needed and the thigh-foot angle is measured. The test is positive for a PLC lesion if there is an increase of at least $10-15^{\circ}$ in comparison to the other knee at $30^{\circ}$ of knee flexion. The test is then repeated at $90^{\circ}$ of flexion, if a further increase in external rotation is present, a PCL lesion is associated.

- External Rotation Recurvatum Test (Hughston \& Norwood, 1980). The patient lies in the supine position with both knees extended. The examiner holds and lifts the great toes of the patient. If a PLC lesion is present, the affected knee hyperextends and goes in varus and in external rotation compared to the contra lateral normal knee.

- Varus Stress test (Hughston et al., 1976; Palmer, 1938). The knee is at $30^{\circ}$ of flexion, the examiner grasps the thigh of the patient with one hand and the foot or the lower leg with the other hand and applies a varus force to the knee. The amount of lateral compartment opening indicates the grade of LCL lesion. I grade (0-5 mm), II grade (6-10 $\mathrm{mm})$, III grade (>10 $\mathrm{mm})$.

- Posterolateral drawer test (Hughston \& Norwood, 1980). The patient lies in the supine position with the knee at $90^{\circ}$ of flexion and the foot $15^{\circ}$ in external rotation while the examiner posteriorly translates the tibia. If the affected limb translates posteriorly more than the contra lateral limb, a popliteus tendon or popliteo-fibular ligament injury are suspected.

- $\quad$ Reverse Pivot Shift test (Jakob et al., 1981). The patient lies in the supine position with the knee at $70^{\circ}-80^{\circ}$ of flexion with the foot externally rotated. If a PLC lesion is present the tibia is posteriorly subluxatated. The knee is subsequently extended and at $20^{\circ}$ of 
flexion this subluxation reduces spontaneously. It is important to consider that the test is positive in $35 \%$ of normal knees, especially under anesthesia, so a side to side comparison is mandatory to evaluate the real amount of instability (Cooper, 1991).

Because meniscal injuries are associated to acute PCL lesions in $16 \%$ to $28 \%$ of cases (Fowler \& Messieh, 1987; Hamada M et al., 2000) and to chronic PCL lesions in 36\% of cases (Geissler \& Whipple, 1993), specific meniscal tests should be systematically performed. Even if neurovascular function tests are more important in acute injury, they also should be performed also in patients with chronic lesions.

\section{Imaging}

Conventional radiology has still an important role in the pre-operative planning of patients with a PCL/PLC lesion, especially if associated to a varus of the knee.

If physical examination reveals any of the following: positive varus stress test, increased varus during thrust, increased tibial external rotation at $30^{\circ}$ of knee flexion or varus recurvatum during standing or walking, stress X-rays should be performed. If X-rays are positive, the patient should get supine full length antero-posterior (A-P) X-rays of both legs to evaluate the real alignment. If physical examination reveals none of the aforementioned features, the patient should get full length double-stance A-P X-rays of both legs. If a varus deformity is not present, the patient should undergo a soft tissue reconstruction; if this deformity is present, it is important to evaluate if a lateral joint line opening is associated. If it is the case, the patient should get stress X-rays, if it is not the case there are two methods described to evaluate the amount of correction to perform during surgery (Dugdale et al., 1992; Noyes et al., 2000).

\subsection{Standard X-ray}

Full length double-stance A-P X-ray is mandatory to evaluate femoro-tibial alignment (Moreland et al., 1987). An A-P. X-ray is taken from the hips to the ankles with the patient standing and the patellae looking forward using a suitable cassette to gradually filter the Xray beam in order to properly visualize both hips and ankles. There are two methods to quantify the amount of correction to perform if a malalignment is present (Dugdale et al., 1992). In both methods a line along the tibial plateau and its intersection with the desired mechanical axis of the lower extremity are marked, in this section this point is called $\mathrm{P}$ for simplicity (see the Indications section for more explanations about the position of $\mathrm{P}$ in each patient). Then a line is traced from the centre of the femoral head to $\mathrm{P}$ and a line is traced from the centre of the tibio-talar joint to P. In the first method the angle formed at the intersection between these two lines represents the amount of correction required (Fig. 6).

In the second method the radiographic film is cut along the osteotomy line and along a vertical line that converge with the first, leaving a $2 \mathrm{~mm}$ hinge at the medial tibial margin, the distal part of the film is rotated until the femoral head, $\mathrm{P}$ and the tibio-talar joint are along the same line; the overlapping wedge margin is the amount of correction to perform. If lateral and/or posterolateral soft tissue structures are insufficient, for every increase of 1 $\mathrm{mm}$ in the lateral joint line width, there is $1^{\circ}$ of added varus. Supine $X$-rays are important to eliminate the added varus due to deficiency of the lateral and/or posterolateral structures and to evaluate the real amount of correction to perform. After HTO the mechanical axis of 
the lower extremity is translated laterally of 3-4 $\mathrm{mm}$ for each $1^{\circ}$ of valgus correction and this value depends on the height of the patient.

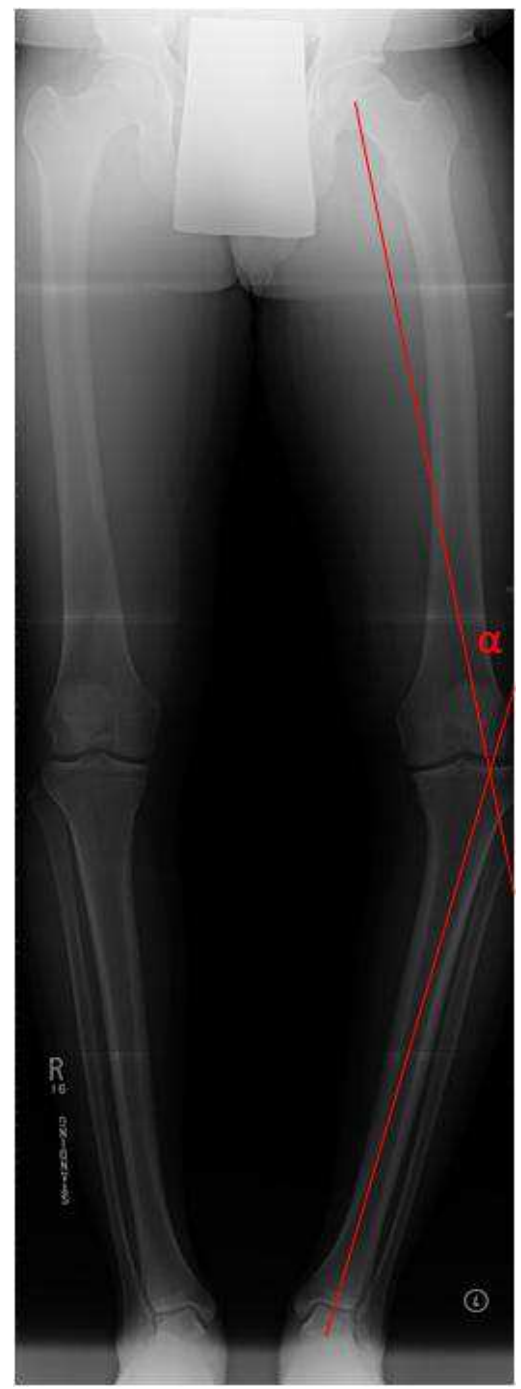

Fig. 6. The angle a represents the correction required

- $\quad$ Real lateral view X-rays are important to evaluate posterior tibial slope. In literature many methods are described to quantify its value (Fig. 7). In all cases a line is traced along the medial tibial plateau, and the angle formed with Proximal Tibial Anatomical Axis (PTAA) (Dejour \& Bonnin, 1994), the anterior tibial cortex (ATC) (Moore \& Harvey, 1974), the posterior tibial cortex (PTC), the proximal fibular anatomical axis (PFAA) and the fibular shaft axis (FSA) (Brazier et al., 1996) is calculated. Between all these techniques the most 
reliable are PTAA and PTC (Brazier et al., 1996). Higher values are found using the ATC method and lower values with PFAA method (Cullù et al., 2005).

- Merchant's view (Merchant et al., 1974) is useful to evaluate patello-femoral joint that can undergo degenerative changes. The patient lies in the supine position with the knees at $45^{\circ}$ of flexion over the end of the table, the knees are sustained to maintain the femora parallel to the horizontal. The X-Ray collimator is placed above the patient and the beam is directed from proximal to distal forming a $30^{\circ}$ angle with the table. The film cassette is placed about $30 \mathrm{~cm}$ below the knees, perpendicular to the tibial shaft.

- Rosemberg's view (Rosenberg et al., 1988) is useful to evaluate the lateral compartment of the knee. The patient stands on both legs with thumbs pointing ahead and the patellae touching the film cassette. The knees are at $45^{\circ}$ of flexion $\left(25^{\circ}\right.$ between the femora and the cassette and $20^{\circ}$ between the tibiae and the cassette), the X-Ray beam is directed from posterior to anterior, $10^{\circ}$ caudal, so the posterior and the anterior margins of the tibial plateau are superimposed.

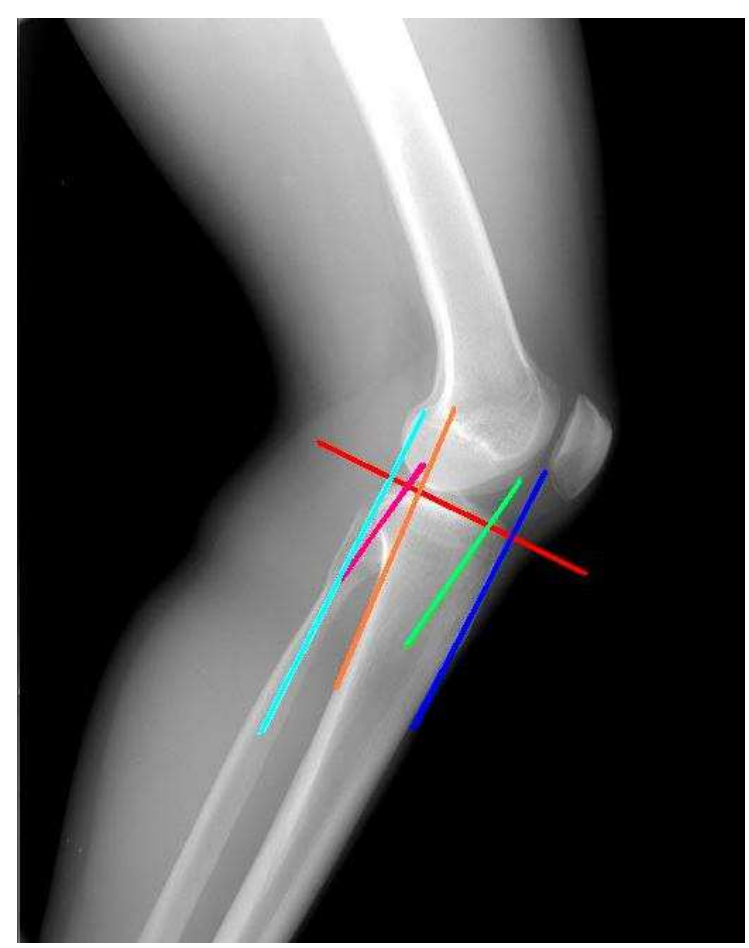

Fig. 7. ATC: Anterior tibial cortex, PTAA: Proximal tibial anatomical axis, PTC: Posterior tibial cortex, PFAA: Proximal fibular anatomical axis, FSA: Fibular shaft axis.

\subsection{Stress X-ray}

- Lateral stress view according to the Telos method (Jacobsen, 1976). The patient lies in the lateral decubitus with the knee flexed at $90^{\circ}$ and is encouraged to relax. The heel is fixed to a stand and the arm of the Telos GA II (Telos, Weterstadt, Germany) applies a 
posterior force to the tibia. In this position a lateral X-Ray is taken. The test is then performed with the knee at $25^{\circ}$ of flexion. This method is very important in chronic PCL deficient knees to evaluate both anterior and posterior tibial translation with regards to the femur and it is useful to detect a fixed posterior tibial subluxation that can be present in $44 \%$ of the patients with a PCL lesion (Strobel et al., 2002).

- Lateral stress view according to the Kneeling method (Louisia et al., 2005). The patient knees on a bench with the knee at $90^{\circ}$ of flexion, the bench only supports the lower legs up to the tibial tubercle. In this position a lateral X-Ray is taken.

- Lateral stress view with hamstring contraction (Chassaing et al., 1995). The patient lies in the lateral decubitus or in the seated position with the knee at $90^{\circ}$ of flexion and the heel fixed to a stand. A lateral X-Ray is taken while the patient contracts his/her hamstring for at least 10 seconds (Chassaing et al., 1995; Jung et al., 2006).

- Lateral stress view according to Gravity method (Staubli \& Jakob, 1990). The patient lies in the supine position with the hip and the knee at $90^{\circ}$ of flexion supported by an assistant, with the leg in neutral rotation. In this position a lateral X-ray is taken.

- Axial stress view (Puddu et al., 2000). The patient lies in the supine position, with both knees at $70^{\circ}$ of flexion, feet plantigrade in moderate plantar flexion and the tibia in neutral rotation. The X-Ray beam is directed parallel to the longitudinal patellar axis, from distal to proximal and the distance between the anterior tibial profile and the centre of the femoral groove is measured. The side to side difference is the amount of posterior instability.

Comparing all these five methods, focusing on posterior translation, side to side difference, condyle rotation, time to perform the test and pain during the test, the most effective methods are Telos at $90^{\circ}$ of knee flexion and Kneeling method, even if they are painful and time consuming procedures. Telos is the most expensive but the most reliable in detecting a posterior tibial subluxation (Jung et al., 2006; Margheritini et al., 2003).

\subsection{MRI}

MRI is useful to evaluate PCL deficient knees, especially associated lesions and subchondral bone (Puddu et al., 2007). Gross et al. (1992) described a classification for PCL lesion that is widely used, however Bellelli et al. (2006) proposed a new MRI classification that considers each PCL bundle independently, emphasizing the importance of SE T2 and STIR sequences. To evaluate PLC, at least 1.5 T MRI scanner is recommended (LaPrade \& Wentorf, 2002), because its sensitivity is $66.7 \%-100 \%$ and its specificity is $66.7 \%-100 \%$, depending on the anatomical structures. Coronal oblique sections (parallel to the popliteus tendon) significantly increases the ability to detect some structures of PLC (i.e. fabello-fibular ligament, arcuate ligament, popliteus tendon and popliteo-fibular ligament) but, also with coronal oblique sections, less than one half of these structures could be imaged ( $\mathrm{Yu}$ et al., 1996). The use thin slice $(2 \mathrm{~mm}$ ) proton density coronal oblique sequences to evaluate LCL and popliteus tendon is also recommended (LaPrade et al., 2000).

We believe that stress radiographs are mandatory in the evaluation of an unstable knee, but do not help the clinician to identify the injured structures. MRI does not solve this problem, because it cannot fully visualize posterolateral structures in at least $50 \%$ of patients ( $\mathrm{Yu}$ et al., 1996). This is still a problem in the diagnosis of a PLC lesion. 


\section{Indications and contraindications}

A wrong indication is the first cause of failure, so surgery must be preceded by an accurate pre-operative planning. Contraindications to HTO are: inflammatory disease, severe tricompartmental OA, severe medial compartment OA, severe lateral compartment OA, severe osteoporosis, high BMI (relative contraindication), individuals older than 65 years (relative), severe patello-femoral OA (relative). There are three causes of failure of HTO in a varus knee: inability to correct the deformity during surgery, a "tibial teeter-totter effect" (advanced medial tibio-femoral OA and obliquity) and a gradual collapse of the medial compartment over years in which the overall alignment drifts back into varus because of continued medial tibio-femoral OA (Noyes et al., 2000).

PCL and PLC lesion are often associated to malalignment of the knee (Fanelli \& Edson, 1995) and they should be corrected 6-8 months after HTO (if the knee is still unstable). In literature poor results for soft tissue procedures alone are reported. This is related to the forces on these structures that do not decrease if the malalignment is not corrected, because a bone deformity overstresses them. Instead HTO reduces these forces and improves the stability and biomechanics of the knee. (See the Biomechanics section for more explanations).

We believe that the evaluation of the deformity in the coronal and the sagittal plane is essential for the treatment of a complex instability of the knee and, before performing any kind of soft tissue surgery, a correct bone alignment should be obtained, both in coronal and in the sagittal plane.

If femoro-tibial OA is present, with narrowing of the medial compartment, the point called $\mathrm{P}$ in the Imaging section should be positioned at $62 \%-66 \%$ of the tibial plateau $(0 \%$ positioned on the medial margin of the tibial plateau and $100 \%$ on the lateral margin). This position increases the pressure on the lateral compartment of the knee (most of the weight of the patient bears on the lateral articular cartilage) (Dugdale et al., 1992; Noyes et al., 2000; Viskontas et al., 2006), indeed a small overcorrection prevents progression of medial compartment OA and an early recurrence of the varus deformity (Akizuki et al., 2008; Noyes et al., 2000). If a degenerative narrowing of the medial compartment is not present the new mechanical axis should split the tibial plateau in two halves (Noyes et al., 2000). Medial opening wedge HTO improves symptoms of patello-femoral OA because the anterior translation of the tibia reduces the tension on the patellar tendon, the patella becomes less horizontal and pressure decreases in the lateral facet (Kumagai et al., 2002; Li et al., 2002). So a patello-femoral pain syndrome is not a contraindication for HTO.

Strobel et al (2002) classified fixed posterior tibial subluxation in three grades: I (3-5 mm), II $(6-10 \mathrm{~mm})$, III $(>10 \mathrm{~mm})$. In first and second grades they recommend a brace in extension with a support under the calf to push the tibia anteriorly (Medi Bayreuth, Bayreuth Germany) because they had good results in $78.4 \%$ and $70.1 \%$ of the patients respectively. In patients with a third grade lesion conservative treatment has given acceptable result only in $32 \%$, so they recommend surgical treatment. If a fixed tibial subluxation is present, it should be reduced before performing any surgical treatment, to avoid an overstress of the graft and an early failure. HTO modifies the tibial slope, provokes the tibia to translate anteriorly and reduces this subluxation. Subsequently, if the knee is still unstable, PCL could be reconstructed. If meniscal lesions are associated, they should be addressed at the same time of HTO. 
Some Authors (Klinger et al., 2001; Ohsawa et al., 2006; Viskontas et al, 2006) suggested that an opening wedge HTO with emicallotaxis and external fixator is the treatment that should be chosen to correct the malalignment, however we prefer to use this technique with a circular external fixator (Taylor Spatial Frame, Smith \& Nephew, Memphis, Tennesseee) only in deformities that need a correction greater than $12.5^{\circ}$. In these cases HTO is associated to a greater rate of complications, such as delayed unions, nonunions and an unstable osteotomy, due to a too large osteotomy gap. If an external fixator is applied, the osteotomy is performed distal to the tibial tubercle and it does not change patellar height, instead medial opening wedge HTO is performed proximal to the tibial tubercle and if the gap is too large, patella infera (baja) may occur. This circular external fixator has a computerized program that consents to achieve a triplanar correction of the deformity and to correct also the tibial slope in the sagittal plane (Catagni et al., 1994). An external fixator consents a slow correction of the deformity, improving consolidation even of large osteotomy gaps, the patient can walk earlier, weight bearing X-Rays could be obtained to evaluate the alignment of the lower limbs, the mechanical axis could be corrected at any time during the elongation phase if needed, without a second surgery being performed and a tourniquet is not needed at the time of surgery (Watanabe et al., 2008). But it is uncomfortable for the patient, it is not easy to wear under normal clothes and pin tract infection may occur. Because the external fixator is not rigid, $5^{\circ}$ of overcorrection reduces the failure rate in case of loss of correction (Catagni et al., 1994).

A preoperative rehabilitation protocol (strengthening of the muscles of the lower limbs and gait retraining) is needed to avoid the recurrence of hyperextension varus trust gait after surgery (Noyes et al., 2000).

HTO and ACL reconstruction are often associated and good results are reported even in knees with double varus. If triple varus is present, HTO should be performed before soft tissue reconstruction, in order to avoid a long surgery and increased risk of postoperative complications (Noyes et al., 2000). We do not have enough patients for a statistical analysis, but in our clinical experience, in a patient with a chronic PCL deficient knee associated with double or triple varus, HTO should be performed before soft tissue procedures. The patient should be evaluated 6-8 months later and, if the knee is still unstable, soft tissue reconstruction should be performed.

\section{Treatment}

A closing wedge lateral HTO and a Dome osteotomy according to Maquet slightly decrease the tibial slope and are not useful in the treatment of a PCL/PLC deficient knee. Because an opening wedge medial HTO and HTO with external fixator consent the surgeon to modify the tibial slope, they are the only osteotomies that can be performed in patients with a PCL/PLC deficient knee, and only these osteotomies are discussed in this section. For the description of lateral HTO, Dome osteotomy and soft tissue procedures the reader is advised to consult the specific literature.

All patients should receive a prophylactic pre-operative dose of intravenous antibiotics; general endotracheal anaesthesia should be preferred because it allows the surgeon to get a bone block from the iliac crest, if needed. With the patient lying in a supine position, the leg is draped in a sterile fashion; if a bone block is needed, the omolateral iliac crest is draped in 
the same fashion. Arthroscopy is performed in all patients to evaluate articular cartilage and menisci and to confirm the indication for HTO (Hernigou et al., 1987; Noyes \& Simon, 1994; Noyes et al., 2000).

If a plate is used to stabilize the osteotomy, the leg is raised and tourniquet is inflated. A vertical incision is performed just behind the pes anserine, between the medial border of the patellar tendon and the posterior border of the tibia. Sartorius fascia is cut to visualize hamstring tendons. Under fluoroscopic control a guide wire is positioned from medial to lateral. The wire is placed at the level of the superior aspect of the tibial tubercle, anteromedially, and it arrives about $1 \mathrm{~cm}$ below the lateral articular margin of the tibia (Fig. 8). A cortical osteotomy is performed with an oscillating saw, inferiorly to the guide wire, and it will be continued with an osteotome under fluoroscopic control (Fig. 9). When the osteotomy is completed, the medial tibia is opened with a wedge of a suitable width (Fig. 10). Wedges have a graduated scale to quantify the angular correction achieved (Hernigou et al., 1987; Noyes \& Simon, 1994; Noyes et al., 2000). The position of the wedge is very

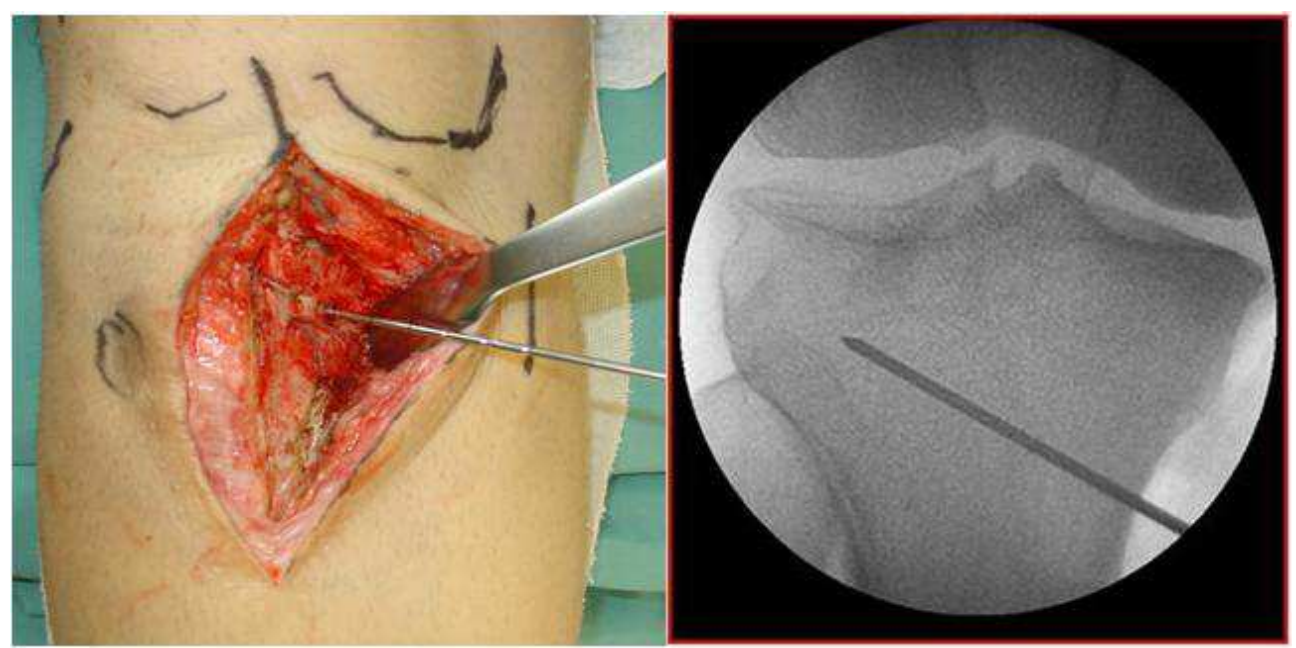

Fig. 8. A guide wire is placed from the superior aspect of the tibial tubercle to about $1 \mathrm{~cm}$ below the lateral articular margin of the tibia.

important in order to correct the deformity on the sagittal plane: a wedge placed anteriorly causes an increase in posterior tibial slope, whereas a posterior wedge tends to slightly decrease the posterior tibial slope (Rodner et al., 2006). Anterior and posterior gaps of the osteotomy are then measured with a ruler, this is important to calculate the amount of increase in posterior tibial slope after surgery (Hohmann et al., 2006). If the anteromedial gap is the half of the postermedial gap, the slope will not change; for each millimetre of increase of the anterior gap, the posterior tibial slope will increase of $2^{\circ}$. An image intensifier and an alignment rod are used to control coronal and sagittal alignment during axial loading of the joint (Noyes et al., 2000) (Fig. 11). If the anterior gap is greater than $1 \mathrm{~cm}$, it is better to perform an osteotomy to lift up the tibial tubercle of the same amount in order to avoid patella infera (baja). Generally to fill the osteotomy gap a carefully shaped bone block from a donor is used. Under fluoroscopic control the final result is checked before the 
tourniquet is deflated, hemostatis and skin suture are then performed (Hernigou et al., 1987; Noyes \& Simon, 1994; Noyes et al., 2000) (Fig. 12). When the correction in the two planes is achieved, the osteotomy is stabilized with a plate with four holes (Arthex, Naples, Florida, USA) with two $6.5 \mathrm{~mm}$ proximal cancellous screws and two $4.5 \mathrm{~mm}$ distal cortical screws (Fig. 13).

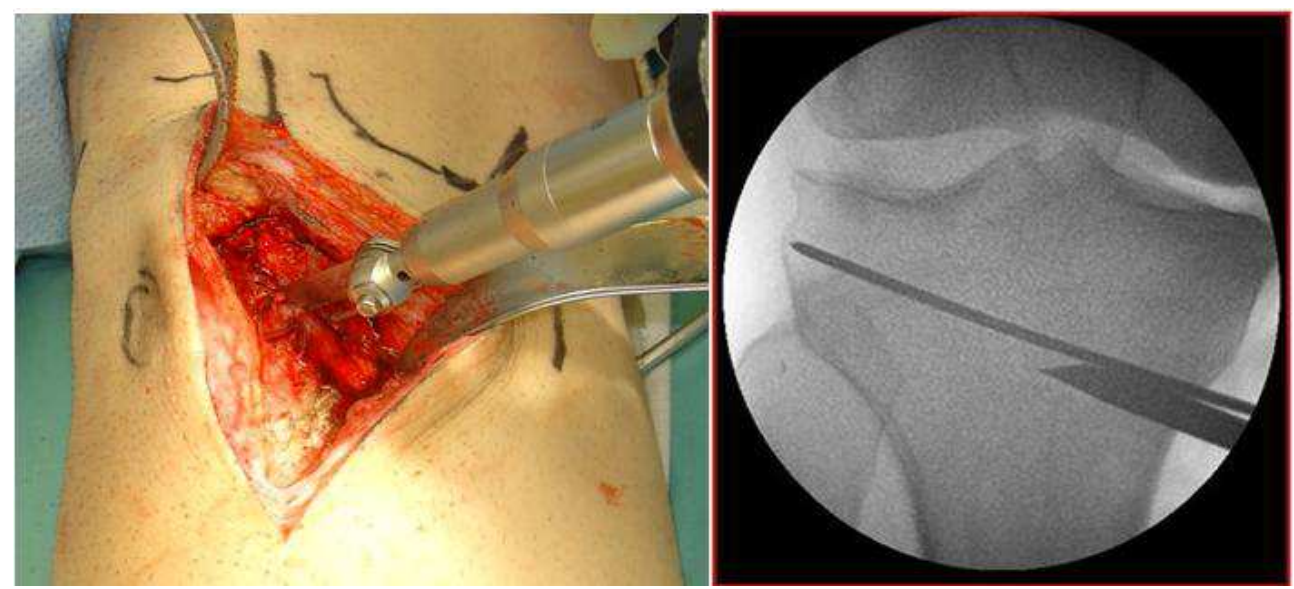

Fig. 9. Cortical osteotomy is performed with an oscillating saw, inferior to the guide wire, and it will be continued with an osteotome.
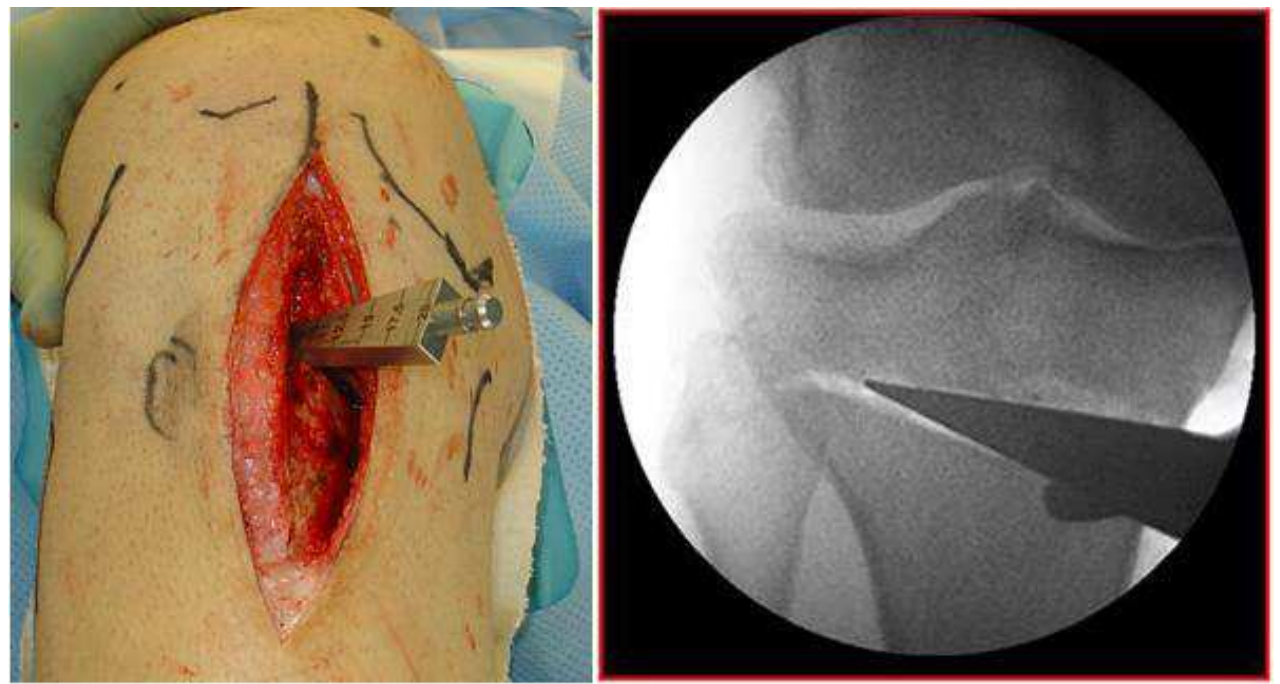

Fig. 10. When the osteotomy is completed, the medial tibia is opened with a wedge of suitable width. 


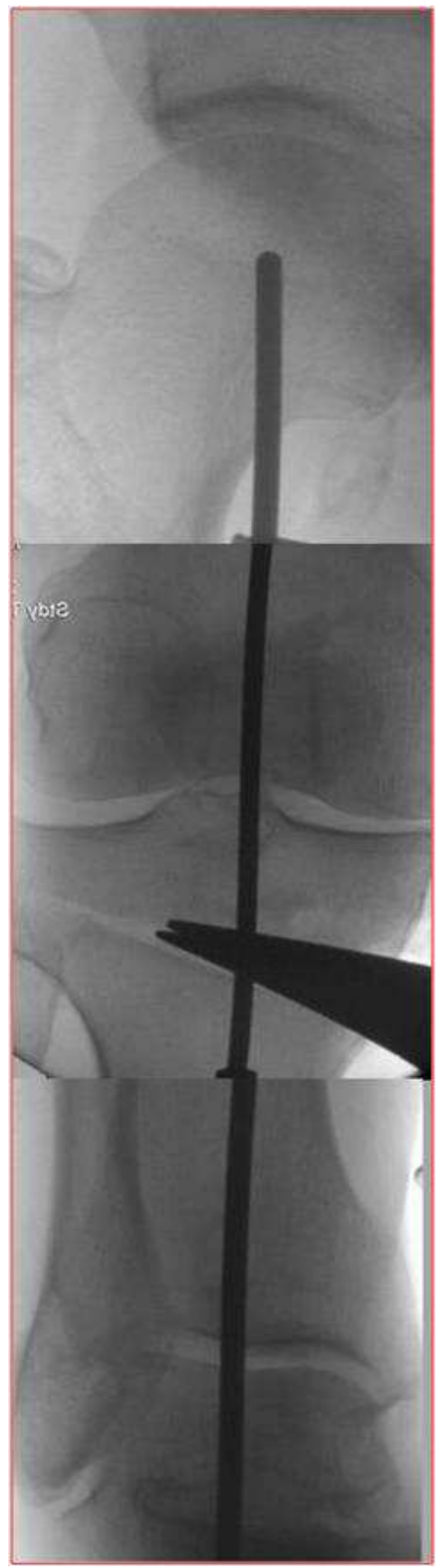

Fig. 11. An image intensifier and an alignment rod are used to control coronal and sagittal alignment during axial loading of the joint. 


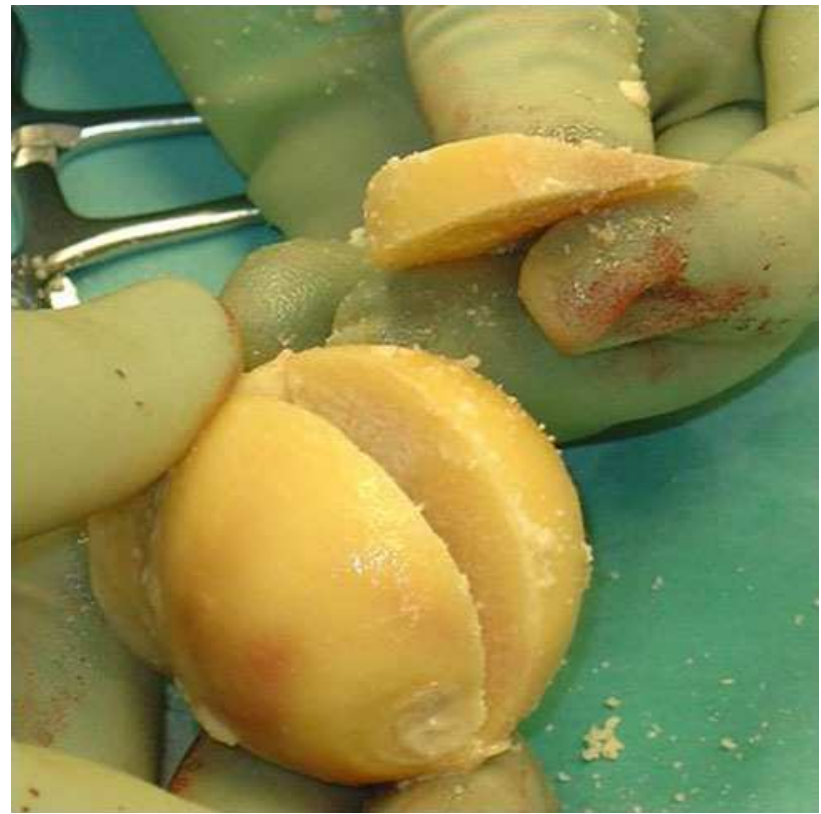

Fig. 12. To fill the osteotomy gap, a carefully shaped bone block from a donor is used.

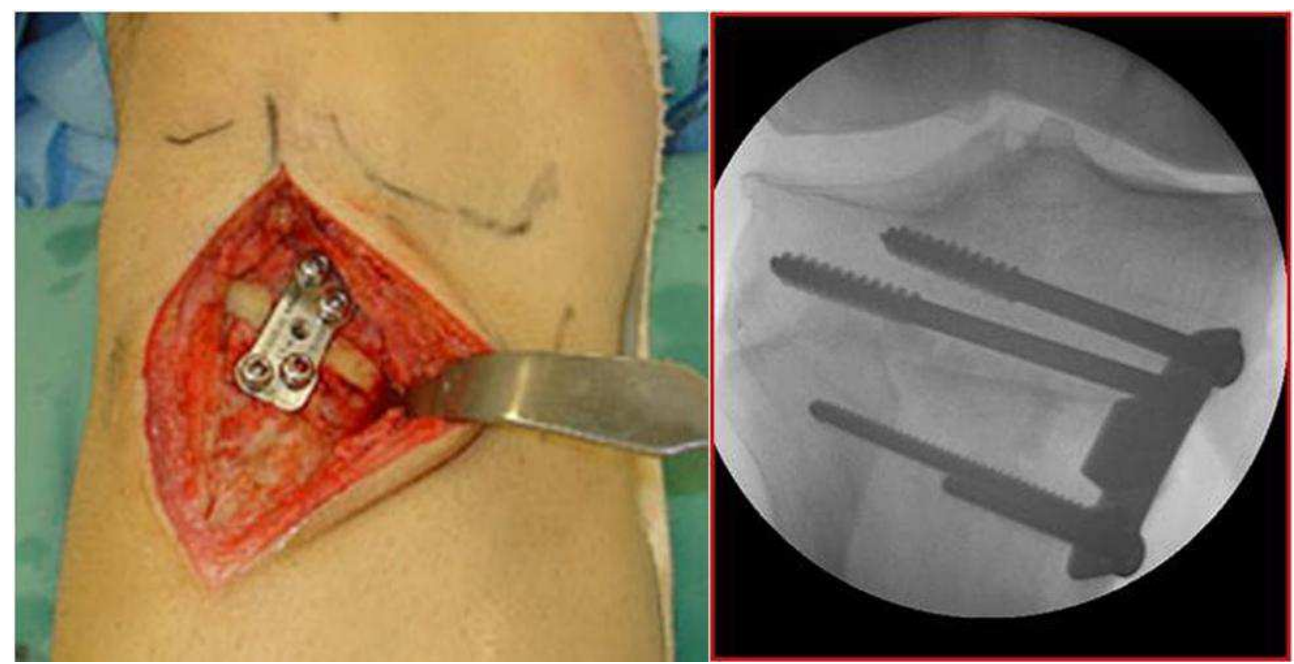

Fig. 13. When correction in the two planes is achieved, the osteotomy is stabilized using a plate with four screws.

Medial opening wedge HTO has some disadvantages like an unstable construct, implant failure, delayed union and nonunions. During surgery it is impossible to exactly predict the position of the mechanical axis during weight bearing, and an overcorrection may occur, requiring a revision surgery (Noyes et al., 2000). 
If an external fixator is used, it is assembled preoperatively on the leg of the patient. Three rings, $4 \mathrm{~cm}$ larger than the diameter of the tibia, are used. The first is positioned at the level of the fibular head, the second $5 \mathrm{~cm}$ below the tibial tubercle, the third $3 \mathrm{~cm}$ proximal to the ankle joint. The first and the second ring are joined with 2 tethered rods and the second and the third rings are joined with 4 tethered rods. The proximal ring is held at an angle equal to the correction needed plus $5^{\circ}$ (to give some overcorrection). The apparatus is then sterilized (Catagni et al., 1994). During surgery a tourniquet in not needed. A $3 \mathrm{~cm}$ incision is made 10 $\mathrm{cm}$ below the fibular head posterolaterally, the plane between soleus and peronei is developed and an oblique fibular osteotomy is performed with an oscillating saw. The external fixator is then applied to the leg of the patient and the first ring is stabilized with two wires and one half pin across the tibia. The second ring is stabilized with one wire and one half pin across the tibia, it is important to avoid to transfix the branches of the superficial peroneal nerve, so the wire should be placed slightly more laterally than the medial aspect of the tibia. The third ring is stabilized with two wires that pass across the tibia and the fibula in order to avoid a distal tibio-fibular subluxation. Then a $1.5 \mathrm{~cm}$ incision is performed anteriorly just distal to the tibial tuberosity, periosteum is elevated on both sides and a tibial osteotomy is performed with an oscillating saw, a drill, a Gigli saw or an osteotome. The required correction can be achieved acutely during surgery by rotating the first two rings until they are parallel to each other. Otherwise, if the osteotomy gap is too large, the correction can be performed gradually, beginning on the $7^{\text {th }}-10^{\text {th }}$ post-operative day, with emicallotaxis technique. The result is verified under image intensifier, a small amount of compression is performed, the rods are tightened and the skin is closed (Catagni et al., 1994; Klinger et al., 2001; Ohsawa et al., 2006; Viskontas et al., 2006).

\section{Post-operative protocol}

The patient should be encouraged not drinking alcohol or smoking. If a plate is used to stabilize the osteotomy, the knee is protected for six weeks in an articulated brace. During this period the patient makes exercises aimed to completely regain the Range Of Motion and reinforce the "Core stability" (Kibler et al., 2006). Only toe-touch gait with crutches is allowed. After six weeks, an X-Ray is performed and the patients is encouraged to increase progressively weight bearing until twelfth week, at that time a second X-Ray is recommended (Christel, 2003). If a circular external fixator is applied, partial weight bearing is allowed immediately without any brace (Catagni et al., 1994)

\section{Conclusion}

HTO is an effective and reliable procedure in the treatment of a PCL/PLC deficient knee associated to varus malalignment. If the knee is still unstable, soft tissue procedures should be performed 6-8 months after the correction of the malalignment. HTO allows the surgeon to modify both the coronal and the sagittal plane of the knee; an increased posterior tibial slope stabilizes the joint, reduces forces of posterolateral structures and on the posterior articular cartilage. However more biomechanical and clinical studies are needed in the future.

\section{References}

Agneskirchner, J.D.; Hurschler, C.; Stukenborg-Colsman, C.; Imhoff, A.B. \& Lobenhoffer, P. (2004) Effect of high tibial flexion osteotomy on cartilage pressure and joint 
kinematics: a biomechanical study in human cadaveric knees. Arch Orthop Trauma Surg, Vol. 124, No. 9, (November), pp. 575-584, ISSN 0936-8051

Ahmad, C.S.; Cohen, Z.A.; Levine, W.N.; Gardner, T.R.; Ateshian, G.A. \& Mow, V.C. (2003) Codominance of the individual posterior cruciate ligament bundles. An analysis of bundle lengths and orientation. Am J Sports Med, Vol. 31, No. 2, (March-April), pp. 221-225, ISSN 0363-5465

Amendola, A.; Rorabeck, C.H.; Bourne, R.B. \& Apyan, P.M. (1989) Total knee arthroplasty following high tibial osteotomy for osteoarthritis. J Arthroplasty, Vol. 4, Suppl., pp. S11-S17, ISSN 0883-5403

Amis, A.A.; Gupte, C.M.; Bull, A.M. \& Edwards, A. (2006) Anatomy of the posterior cruciate ligament and the meniscofemoral ligaments. Knee Surg Sports Traumatol Arthrosc, Vol. 14, No. 3 (March), pp. 257-263. Review, ISSN 0942-2056.

Akizuki, S.; Shibakawa, A.; Takizawa, T.; Yamazaki, I. \& Horiuchi, H. (2008) The long-term outcome of high tibial osteotomy: a ten- to 20-year follow-up. J Bone Joint Surg Br, Vol. 90, No. 5 (May), pp. 592-596, ISSN 0301-620X

Badhe, N.P. \& Forster, I.W. (2002) High tibial osteotomy in knee instability: the rationale of treatment and early results. Knee Surg Sports Traumtol Arthros, Vol. 10, No. 1 (January), pp. 38-43, ISSN 0942-2056

Barton, T.M.; Torg, J.S. \& Das, M. (1984) Posterior cruciate ligament insufficiency. A review of the literature. Sports Med, Vol. 1, No. 6, (November-December), pp. 419-430. Review, ISSN 0112-1642

Bellelli, A.; Mancini, P.; Polito, M.; David, V. \& Mariani, P.P. (2006) Magnetic resonance imaging of posterior cruciate ligament injuries: a new classification of traumatic tears. Radiol Med, Vol. 111, No. 6, (September), pp. 828-35, ISSN: 0033-8362.

Boileau, P. \& Neyret P.H. (1991) Resultats des osteotomies tibialis de valgisation assoiees aux plasties du ligament croise' anterieur dans le traitment des laxites anterieures chronique evoluees. In: 7èmes journèes lyonnaises de chirurgie du genu, Lyon, pp 232249, ISBN 28533415509782853341554

Bonnin, M. (1990) La subluxation tibiale anterieure en appui monopodal dans les ruptures du ligament croise anterieur. Etude clinic et biomechanique (thesis). Lyon, France: Université Claude Bernard.

Brazier, J.; Migaud, H.; Gougeon, F.; Cotten, A.; Fontaine, C. \& Duquennoy A. (1996) Evaluation of methods for radiographic measurement of the tibial slope. A study of 83 healthy knee. Rev Chir Orthop Reparatrice Appar Mot, Vol. 82, No. 3, pp. 195-200, ISSN 0035-1040

Catagni, M.A.; Guerreschi, F.; Ahmad, T.S. \& Cattaneo, R. (1994) Treatment of genu varum in medial compartment osteoarthritis of the knee using the Ilizarov method. Orthop Clin North Am. Vol. 25, No. 3, (July), pp. 509-514, ISSN 0030-5898

Chang, A.; Hayes, K.; Dunlop, D.; Hurwitz, D.; Song, J.; Cahue, S.; Genge, R.; \& Sharma L. (2004) Thrust during ambulation and the progression of knee osteoarthritis. Arthritis Rheum, Vol. 50, No. 12, (December), pp. 3897-3903, ISSN: 1529-0131

Chassaing, V.; Deltour, F.; Touzard, R.; Ceccaldi, J.P. \& Miremad, C. (1995) Etude radiologique du L.C.P.'a 90 de flexion. Rev Chir Orthop, Vol. 81, pp. 35-38, ISSN 0035-1040

Chiu, K.Y.; Zhang, S.D. \& Zhang, G.H. (2000) Posterior slope of tibial plateau in Chinese. J Arthroplasty, Vol. 15, No. 2 (February), pp. 224-227, ISSN 0883-5403 
Christel P. (2003) Basic principles for surgical reconstruction of the PCL in chronic posterior knee instability. Knee Surg Sports Traumatol Arthrosc, Vol. 11, No. 5, (September), pp. 289-296. Review, ISSN 0942-2056

Cooper DE. (1991) Tests for posterolateral instability of the knee in normal subjects. J Bone Joint Surg Am, Vol. 73, No. 1, (January), pp 30-36, ISSN 1535-1386

Coventry, M.B.; Ilstrup, D.M. \& Wallrichs, S.L. (1993) Proximal tibial osteotomy: A critical long-term study of eighty-seven cases. J Bone Joint Surg Am, Vol. 75, No. 2, (February), pp 196-201, ISSN 1535-1386

Cullù, E.; Aydogdu, S.; Alparslan, B. \& Sur, H. (2005) Tibial slope changes following dometype high tibial osteotomy. Knee Surg Sports Traumatol Arthrosc, Vol. 13, No. 1 (January), pp. 38-43, ISSN 0942-2056

Daniel, D.M.; Stone, M.L.; Barnett, P. \& Sachs, R. (1988) Use of the quadriceps active test to diagnose posterior cruciate-ligament disruption and measure posterior laxity of the knee. J Bone Joint Surg Am, Vol. 70, No. 3, (March), pp. 386-391, ISSN 1535-1386

Dejour, H. \& Bonnin, M. (1994) Tibial translation after anterior cruciate ligament rupture. Two radiological tests compared. J Bone Joint Surg Br, Vol. 76, No. 5, (September), pp. 745-749, ISSN 0301-620X

Dejour, H.; Neyret, P. \& Bonnin, M. (1994) Instability and Osteoarthritis, in: Knee Surgery. Fu FH, Harner CD, Vince KG (eds), pp . 859-875, Williams \& Wilkins, ISBN: 0683033891, Baltimore,

Dugdale, T.W.; Noyes, F.R. \& Styer, D. (1992) Preoperative planning for high tibial osteotomy. The effect of lateral tibiofemoral separation and tibiofemoral length. Clin Orthop Relat Res, Vol. 274 (January), pp. 248-264. Review, ISSN 0009-921X

Fanelli, G.C. \& Edson, C.J. (1995) Posterior cruciate ligament injuries in trauma patients: Part II. Arthroscopy, Vol. 11, No. 5, (October), pp. 526-529, ISSN 0749-8063

Fowler, P.J. \& Messieh, S.S. (1987) Isolated posterior cruciate ligament injuries in athletes. Am J Sports Med, Vol. 15, No. 6, (November-December), pp. 553-557, ISSN 03635465

Fowler, P.J.; Kirkley, A. \& Roe, J. (1994) Osteotomy of the proximal tibia in the treatment of chronic anterior cruciate ligament insufficiency. J Bone Joint Surg Br, Vol. 76, Supp 26, ISSN 0301-620X

Fujisawa, Y.; Masuhara, K.; Shiomi, S. (1979) The effect of high tibial osteotomy on osteoarthritis of the knee. An arthroscopic study of 54 knee joints. Orthop Clin North Am, Vol. 10, No. 3, (July), pp. 585-608, ISSN 0030-5898

Geissler, W.B. \& Whipple, T.L. (1993) Intraarticular abnormalities in association with posterior cruciate ligament injuries. Am J SportsMed, Vol. 21, No. 6, (NovemberDecember), pp. 846-849, ISSN 0363-5465

Genin, P.; Weill, G. \& Julliard, R. (1993) The tibial slope. Proposal for a measurement method. J Radiol. Vol. 74, No. 1, (January), pp. 27-33. Review.

Giffin, J.R.; Vogrin, T.M.; Zantop, T.; Woo, S.L. \& Harner, C.D. (2004) Effects of increasing tibial slope on the biomechanics of the knee. Am J Sports Med. Vol. 32, No. 2, (March), pp. 376-382, ISSN 0363-5465

Giffin, J.R.; Stabile, K.J.; Zantop, T.; Vogrin, T.M.; Woo, S.L. \& Harner, C.D. (2007) Importance of Tibial Slope for Stability of the Posterior Cruciate Ligament-Deficient Knee. Am J Sports Med, Vol. 35, No. 9, )September), pp. 1443-1449, ISSN 0363-5465

Goradia, V.K. \& Van Allen, J. (2002) Chronic lateral knee instability treated with a high tibial osteotomy. Arthroscopy, Vol. 18, No. 7, (September), pp. 807-811, ISSN 0749-8063 
Gross, M.L.; Grover, J.S.; Bassett, L.W.; Seeger, L.L. \& Finerman, G.A. (1992) Magnetic resonance imaging of the posterior cruciate ligament. Clinical use to improve diagnostic accuracy. Am J Sports Med, Vol. 20, No. 6, (November-December), pp. 732-737, ISSN 0363-5465

Hamada, M.; Shino, K.; Mitsuoka, T.; Toritsuka, Y.; Natsu-Ume, T. \& Horibe, S. (2000) Chondral injury associated with acute isolated posterior cruciate ligament injury. Arthroscopy, Vol. 16, No. 1, (January-February), pp. 59-63, ISSN 0749-8063

Hernigou, P.; Medevielle, D.; Debeyre, J. \& Goutallier, D. (1987) Proximal tibial osteotomy for osteoarthritis with varus deformity. A ten to thirteen-year follow-up study. $J$ Bone Joint Surg Am, Vol. 69, No. 3, (March), pp. 332-354, ISSN 1535-1386

Hoher, J.; Harner, C.D.; Vogrin, T.M.; Baek, G.H.; Carlin, G.J. \& Woo, S.L. (1998) In situ forces in the posterolateral structures of the knee under posterior tibial loading in the intact and posterior cruciate ligament-deficient knee. J Orthop Res, Vol. 16, No. 6, (November), pp. 675-681, ISSN 1554-527X

Hohmann, E.; Bryant, A. \& Imhoff, A.B. (2006) The effect of closed wedge high tibial osteotomy on tibial slope: a radiographic study. Knee Surg Sports Traumatol Arthrosc, Vol. 14, No. 5, (May), pp. 454-459, ISSN 0942-2056

Hoppenfeld, S.; deBoer, P. (2003) The Tibia and Fibula. In: Surgical Exposures in Orthopaedics: The Anatomic Approach, 3rd Edition, Lippincott Williams \& Wilkins, ISBN-10: 0781742285

Hughston, J.C.; Andrews, J.R.; Cross, M.J. \& Moschi, A. (1976) Classification of knee ligament instabilities: Part II. The lateral compartment. J Bone Joint Surg Am, Vol. 58, No. 2, (March), pp.173-179, ISSN 1535-1386

Hughston, J.C. \& Norwood, L.A. Jr. (1980) The posterolateral drawer test and external rotational recurvatum test for posterolateral rotatory instability of the knee. Clin Orthop Relat Res, Vol. 147, (March-April), pp. 82-87, ISSN 0009-921X

Insall, J.N.; Joseph, D.M. \& Msika, C. (1984) High tibial osteotomy for varus gonarthrosis. A long-term follow-up study. J Bone Joint Surg Am, Vol. 66, No. 7, (September), pp. 1040-1048, ISSN 1535-1386

Insall, J.N. (1993) Total knee arthroplasty in rheumatoid arthritis. Ryumachi, Vol. 33, No. 6, (December), pp. 472, ISSN 0300-9157

Jakob, R.P.; Hassler, H. \& Staubli, H.U. (1981) Observations on rotator instability of the lateral compartment of the knee. Experimental studies of the functional anatomy and pathomechanism of the true and reverse pivot shift sign. Acta Orthop Scand Suppl, Vol. 191, pp. 1-32, ISSN 0001-6470

Jacobsen, K. (1976) Stress radiographical measurement of the anteroposterior, medial and lateral stability of the knee joint. Acta Orthop Scand, Vol. 47, No, 3, (June), pp. 335-4, ISSN 0001-6470

Jung, T.M.; Reinhardt, C.; Scheffler, S.U. \& Weiler, A. (2006) Stress radiography to measure posterior cruciate ligament insufficiency: a comparison of five different techniques. Knee Surg Sports Traumatol Arthrosc, Vol. 14, No. 11, (November), pp. 1116-1121, ISSN 0942-2056

Kibler, W.B.; Press, J. \& Sciascia A. (2006) The role of core stability in athletic function. Sports Med, Vol. 36, No. 3, pp. 189-198, ISSN 0112-1642

Klinger, H.M.; Lorenz, F.; Harer, T. (2001) Open wedge tibial osteotomy by hemicallotasis for medial compartment osteoarthritis. Arch Orthop Trauma Surg, Vol. 121, No. 5, (May), pp. 245-247, ISSN 0936-8051 
Kumagai, M.; Mizuno, Y.; Mattessich, S.M.; Elias, J.J.; Cosgarea, A.J. \& Chao, E.Y. (2002) Posterior cruciate ligament rupture alters in vitro knee kinematics. Clin Orthop Relat Res, Vol. 395, pp. 241-248, ISSN 0009-921X

Krudwig, W.K.; Witzel, U. \& Ullrich, K. (2002) Posterolateral aspect and stability of the knee joint. II. Posterolateral instability and effect of isolated and combined posterolateral reconstruction on knee stability: a biomechanical study. Knee Surg Sports Traumatol Arthrosc, Vol. 10, No. 2, (March), pp. 91-95, ISSN 0942-2056

LaPrade, R.F. \& Terry, G.C. (1997) Injuries to the posterolateral aspect of the knee: association of anatomic injury patterns with clinical instability. Am J Sports Med, Vol. 25, No. 4, (July-August), pp. 433-438, ISSN 0363-5465

LaPrade, R.F.; Gilbert, T.J.; Bollom, T.S.; Wentorf, F. \& Chaljub, G. (2000) The magnetic resonance imaging appearance of individual structures of the posterolateral knee. A prospective study of normal knees and knees with surgically verified grade III injuries. Am J Sports Med, Vol. 28, No. 2, (March-April), pp. 191-199, ISSN 0363-5465

LaPrade, R.F. \& Wentorf, F. (2002) Diagnosis and treatment of posterolateral knee injuries. Clin Orthop Relat Res, Vol. 402, (September), pp. 110-121. Review, ISSN 0009-921X

Lattermann, C. \& Jakob, R.P. (1996) High tibial osteotomy alone or combined with ligament reconstruction in anterior cruciate ligament-deficient knees. Knee Surg Sports Traumatol Arthrosc, Vol. 4, No. 1, pp. 32-38, ISSN 0942-2056

Lecuire, F.; Lerat, J.L.; Bousquet, G.; Dejour, H. \& Trillat, A. (1980) The treatment of genu recurvatum. Rev Chir Orthop Reparatrice Appar Mot, Vol. 66, No. 2, (March), pp. 95103, ISSN 0035-1040

Lephart, S.M.; Pincivero, D.M. \& Rozzi, S.L. (1998) Proprioception of the ankle and knee. Sports Med, Vol. 25, No. 3, (March), pp. 149-155. Review, ISSN 0112-1642

Lerat, J.L.; Moyen, B.; Garin, C.; Mandrino, A.; Besse, J.L. \& Brunet-Guedj, E. (1993) Anterior laxity and internal arthritis of the knee. Results of the reconstruction of the anterior cruciate ligament associated with tibial osteotomy. Rev Chir Orthop Reparatrice Appar Mot, Vol. 79, No. 5, pp. 365-374, ISSN 0035-1040

Levigne, C.H. \& Bonnin, M. (1991) Osteotomie tibiale de valgisation pour arthrose femorotibale interne. In: 7èmes journees lyonnaise de chirurgie du genu, Lyon, pp 142-168, ISBN 28533415509782853341554

Li, G.; Gill, T.J.; DeFrate, L.E.; Zayontz, S.; Glatt, V. \& Zarins, B. (2002) Biomechanical consequences of PCL deficiency in the knee under simulated muscle loads-an in vitro experimental study. J Orthop Res, Vol. 20, No. 4, (July), pp. 887-892, ISSN 1554$527 X$

Loomer, R.L. (1991) A test for knee posterolateral rotatory instability. Clin Orthop Relat Res, Vol. 264, (March), pp. 235-238, ISSN 0009-921X

Louisia, S.; Siebold, R.; Canty, J. \& Bartlett, R.J. (2005) Assessment of posterior stability in total knee replacement by stress radiographs: prospective comparison of two different types of mobile bearing implants. Knee Surg Sports Traumatol Arthrosc, Vol. 13, No. 6, (September), pp. 476-48, ISSN 0942-2056

Maquet, P. Valgus osteotomy for osteoarthritis of the knee. (1976) Clin Orthop Relat Res, Vol. 120, (October), pp. 143-148, ISSN 0009-921X

Margheritini, F.; Mancini, L.; Mauro, C.S.; Mariani, P.P. (2003) Stress radiography for quantifying posterior cruciate ligament deficiency. Arthroscopy, Vol. 19, No. 7, (September), pp. 706-711, ISSN 0749-8063 
Marti, C.B.; Gautier, E.; Wachtl, S.W. \& Jakob, R.P. (2004) Accuracy of frontal and sagittal plane correction in open-wedge high tibial osteotomy. Arthroscopy, Vol. 20, No. 4, (April), pp. 366-372. Review, ISSN 0749-8063

Matsuda, S.; Miura, H.; Nagamine, R.; Urabe, K.; Ikenoue, T.; Okazaki, K. \& Iwamoto, Y. (1999) Posterior tibial slope in the normal and varus knee. Am J Knee Surg, Vol. 12, No. 3, pp. 165-168, ISSN 0899-7403

Mayo Robson, A.W. (1903) Ruptured cruciate ligament and their repair by operation. Ann Surg Engl. Vol. 37, No. 5, (May), pp.716-718, ISSN 0003-4932

Merchant, A.C.; Mercer, R.L.; Jacobsen, R.H. \& Cool, C.R. (1974) Roentgenographic analysis of patellofemoral congruence. J Bone Joint Surg Am, Vol. 56, No. 7, (October), pp. 1391-1396, ISSN 1535-1386

Miller, M.D.; Cooper, D.E.; Fanelli, G.C.; Harner, C.D. \& LaPrade, R.F. (2002) Posterior cruciate ligament: current concepts. Instr Course Lect, Vol. 51, pp. 347-351. Review, ISSN 0065-6895

Moore, T.M. \& Harvey, J.P. Jr. (1974) Roentgenographic measurement of tibial-plateau depression due to fracture. J Bone Joint Surg Am, Vol. 56, No. 1, (January), pp. 155160, ISSN 1535-1386

Moreland, J.R.; Bassett, L.W. \& Hanker, G.J. (1987) Radiographic analysis of the axial alignment of the lower extremity. J Bone Joint Surg Am, Vol. 69, No. 5, (June), pp. 745-749, ISSN 1535-1386

Nagel, A.; Insall, J.N. \& Scuderi, G.R. (1996) Proximal tibial osteotomy: A subjective outcome study. J Bone Joint Surg Am, Vol. 78, No. 9, (September), pp. 1353-1358, ISSN 15351386

Nakamura, E.; Mizuta, H.; Kudo, S.; Takagi, K. \& Sakamoto, K. (2001) Open-wedge osteotomy of the proximal tibia hemicallotasis. J Bone Joint Surg Br, Vol. 83, No. 8, (November), pp. 1111-1115, ISSN 0301-620X

Naudie, D.D.; Amendola, A. \& Fowler, P.J. (1994) Opening wedge high tibial osteotomy for symptomatic hyperextension-varus thrust. Am J Sports Med, Vol. 32, No.1, (JanuaryFebruary), pp. 60-70, ISSN 0363-5465

Naudie, D.D.; Bourne, R.B.; Rorabeck, C.H. \& Bourne, T.J. (1999) The Install Award. Survivorship of the high tibial valgus osteotomy. A 10- to -22-year followup study. Clin Orthop Relat Res, Vol. 367, (October), pp.18-27, ISSN 0009-921X

Neuschwander, D.C.; Drez, D. Jr. \& Paine, R.M. (1993) Simultaneous high tibial osteotomy and ACL reconstruction for combined genu varum and symptomatic ACL tear. Orthopedics, Vol. 16, No. 6, (June), pp. 679-684, ISSN 0147-7447

Neyret, P.; Donell, S.T. \& Dejour, H. (1993) Results of partial meniscectomy related to the state of the anterior cruciate ligament. Review at 20 to 35 years. J Bone Joint Surg Br, Vol. 75, No. 1, (January), pp. 36-40, ISSN 0301-620X

Noyes, F.R.; Barber-Westin, S.D. \& Simon, R. (1993) High tibial osteotomy and ligament reconstruction in varus angulated, anterior cruciate ligament-deficient knees. A two-to-seven year follow-up study. Am J Sports Med, Vol. 21, No. 1, (JanuaryFebruary), pp. 2-12, ISSN 0363-5465

Noyes, F.R. \& Simon, R. (1994) The role of high tibial osteotomy in the anterior cruciate ligament-deficient knee with varus alignment, In: Orthopaedic Sports Medicine. Principles and Practice, DeLee J.C. \& Drez D, pp 1401-1443, WB Saunders, ISBN-10: 0721688454, Philadelphia, 
Noyes, F.R.; Dunworth, L.A.; Andriacchi, T.P.; Andrews, M. \& Hewett, T.E. (1996) Knee hyperextension gait abnormalities in unstable knees. Recognition and preoperative gait retraining. Am J Sports Med, Vol. 24, No. 1, (January-February), pp. 35-45, ISSN 0363-5465

Noyes, F.R.; Barber-Westin, S.D. \& Hewett, T.E. (2000) High tibial osteotomy and ligament reconstruction for varus angulated anterior cruciate ligament-deficient knees. Am J Sports Med, Vol. 28, No. 3, (May-June), pp. 282-296, ISSN 0363-5465

Noyes, F.R.; Barber-Westin, S.D. \& Rankin, M. (2004) Meniscal transplantation in symptomatic patients less than fifty years old. J Bone Joint Surg Am, Vol. 86, No. 7, (July), pp. 1392-1404, ISSN 1535-1386

Noyes, F.R.; Goebel, S.X. \& West, J. (2005) Opening wedge tibial osteotomy: the 3-triangle method to correct axial alignment and tibial slope. Am J Sports Med, Vol. 33, No. 3, (March), pp. 378-387, ISSN 0363-5465

Ochi, M.; Murao, T.; Sumen, Y.; Kobayashi, K. \& Adachi, N. (1999) Isolated posterior cruciate ligament insufficiency induces morphological changes of anterior cruciate ligament collagen fibrils. Arthroscopy, Vol. 15, No. 3, (April), pp. 292-296, ISSN 0749-8063

Odenbring, S.; Egund, N.; Lindstrand, A.; Lohmander, L.S. \& Willen, H. (1992) Cartilage regeneration after proximal tibial osteotomy for medial gonarthrosis. An arthroscopic, roentgenographic, and histologic study. Clin Orthop Relat Res, Vol. 277, (April), pp. 210-216, ISSN 0009-921X

Ohsawa, S.; Hukuda, K.; Inamori, Y. \& Yasui, N. (2006) High tibial osteotomy for osteoarthritis of the knee with varus deformity utilizing the hemicallotasis method. Arch Orthop Trauma Surg, Vol. 126, No. 9, (November), pp. 588-593, ISSN 0936-8051

Paessler, H.H. \& Michel, D. (1992) How new is the Lachman test? Am J Sports Med, Vol. 20, No. 1, (January-February), pp. 95-98, ISSN 0363-5465

Paley, D.R. (2002) Principles of Deformity Correction, Springer-Verlag, ISBN 3-540-41665-X, Berlin.

Paley, D.R.; Herzenberg, J.E.; Tetsworth, K.; McKie, J. \& Bhave, A. (1994) Deformity planning for frontal and sagittal plane corrective osteotomies. Orthop Clin North Am, Vol. 25, No 3, (July), pp. 425-465. Review, ISSN 0030-5898

Palmer, I. (1938) On injuries the ligaments of the knee joint. A clinical study. Acta Chir Scand Suppl, Vol. 53, pp. 282, ISSN 0301-1860

Petrigliano, F.A.; McAllister, D.R. (2006) Isolated Posterior Cruciate Ligament Injuries of the Knee. Sports Med Arthrosc Rev, Vol. 14, No. 4, (December), pp. 206-212, ISSN 1062-8592

Puddu, G.; Gianni, E.; Chambat, P. \& De Paulis, F. (2000) The axial view in evaluating tibial translation in cases of insufficiency of the posterior cruciate ligament. Arthroscopy, Vol. 16, No. 2, (March), pp. 217-220, ISSN 0749-8063

Puddu, G.; Cipolla, M.; Cerullo, G.; Franco, V. \& Gianni E. (2007) Osteotomies: the surgical treatment of the valgus knee. Sports Med Arthrosc, Vol. 15, No. 1, (March), pp. 15-22. Review, ISSN 1062-8592

Ramaniraka, N.A.; Terrier, A.; Theumann, N. \& Siegrist, O. (2005) Effects of the posterior cruciate ligament reconstruction on the biomechanics of the knee joint: a finite element analysis. Clin Biomech (Bristol, Avon), Vol. 20, No. 4, (May), pp. 434-442, ISBN/ISSN 02680033

Rodner, C.M.; Adams, D.J.; Diaz-Doran, V.; Tate, J.P.; Santangelo, S.A.; Mazzocca, A.D. \& Arciero, R.A. (2006) Medial opening wedge tibial osteotomy and the sagittal plane: 
the effect of increasing tibial slope on tibiofemoral contact pressure. Am J Sports Med, Vol. 34, No. 9, (September), pp. 1431-1441, ISSN 0363-5465

Rosenberg, T.D.; Paulos, L.E.; Parker, R.D.; Coward, D.B. \& Scott, S.M. (1988) The forty-fivedegree posteroanterior flexion weight-bearing radiograph of the knee. J Bone Joint Surg Am, Vol. 70, No. 10, (December), pp. 1479-1483, ISSN 1535-1386

Rubinstein, R.A. Jr.; Shelbourne, K.D.; McCarroll, J.R.; VanMeter, C.D. \& Rettig, A.C. (1994) The accuracy of the clinical examination in the setting of posterior cruciate ligament injuries. Am J Sports Med, Vol. 22, No. 4, (July-August), pp. 550-557, ISSN 0363-5465

Safran, M.R.; Allen, A.A.; Lephart, S.M.; Borsa, P.A.; Fu, F.H. \& Harner, CD. (1999) Proprioception in the posterior cruciate ligament deficient knee. Knee Surg Sports Traumatol Arthrosc, Vol. 7, No. 5, pp. 310-317, ISSN 0942-2056

Seebacher, J.R.; Inglis, A.E.; Marshall, J.L. \& Warren, R.F. (1982) The structure of the posterolateral aspect of the knee. J Bone Joint Surg Am, Vol. 64, No. 4, (April), pp. 536-541, ISSN 1535-1386

Skyhar, M.J.; Warren, R.F.; Ortiz, G.J.; Schwartz, E. \& Otis, J.C. (1993) The effects of sectioning of the posterior cruciate ligament and the posterolateral complex on the articular contact pressures within the knee. J Bone Joint Surg Am, Vol. 75, No. 5, (May), pp. 694-699, ISSN 1535-1386

Staubli, H.U. \& Jakob, R.P. (1990) Posterior instability of the knee extension. A clinical and stress radiographic analysis of acute injuries of the posterior cruciate ligament. $J$ Bone Joint Surg Br, Vol. 72, No. 2, (March), pp. 225-230, ISSN 0301-620X

Strobel, M.; Stedtfeld, H.W.; Feagia, J.A. \& Telger, T.C. (1990) Diagnostic evaluation of the knee, Springer-Verlag, ISBN-10: 3540507108, New York

Strobel, M.J.; Weiler, A. \& Eichhorn HJ. (2000) Diagnosis and therapy of fresh and chronic posterior cruciate ligament lesions: Chirurg, Vol. 71, No. 9, (September), pp. 10661081. Review, ISSN 0009-4722

Strobel, M.J.; Weiler, A.; Schulz, M.S.; Russe, K. \& Eichhorn, H.J. (2002) Fixed posterior subluxation in posterior cruciate ligament-deficient knees: diagnosis and treatment of a new clinical sign. Am J Sports Med, Vol. 30, No. 1, (January-February), pp. 3238, ISSN 0363-5465

Takahashi, M.; Matsubara, T.; Doi, M.; Suzuki, D. \& Nagano A. (2006) Anatomical study of the femoral and tibial insertions of the anterolateral and posteromedial bundles of human posterior cruciate ligament. Knee Surg Sports Traumatol Arthrosc, Vol. 14, No. 11, (November), pp. 1055-1059, ISSN 0942-2056

Veltri, D.M. \& Warren, R.F. (1994) Anatomy, biomechanics, and physical findings in posterolateral knee instability. Clin Sports Med, Vol. 13, No. 3, (July), pp. 599-614. Review, ISSN 0112-1642

Viskontas, D.G.; MacLeod, M.D. \& Sanders, D.W. (2006) High tibial osteotomy with use of the Taylor Spatial Frame external fixator for osteoarthritis of the knee. Can J Surg, Vol. 49, No. 4, (August), pp. 245-250, ISSN 0008-428X

Watanabe, K.; Tsuchiya, H.; Matsubara, H.; Kitano, S. \& Tomita, K. (2008) Revision high tibial osteotomy with the Taylor spatial frame for failed opening-wedge high tibial osteotomy. J Orthop Sci, Vol. 13, No. 2, (March), pp. 145-149, ISSN 0949-2658

Yu, J.S.; Salonen, D.C.; Hodler, J.; Haghighi, P.; Trudell, D. \& Resnick, D. (1996) Posterolateral aspect of the knee: improved MR imaging with a coronal oblique technique. Radiology, Vol. 198, No. 1, pp. 199-204, ISSN 0033-8419 


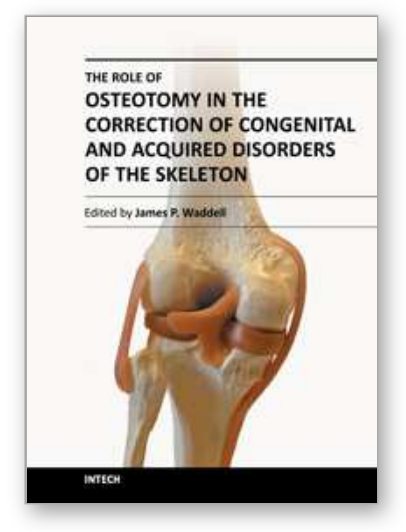

\author{
The Role of Osteotomy in the Correction of Congenital and \\ Acquired Disorders of the Skeleton \\ Edited by Prof. James Waddell
}

ISBN 978-953-51-0495-7

Hard cover, 294 pages

Publisher InTech

Published online 11, April, 2012

Published in print edition April, 2012

This book demonstrates specific osteotomy techniques from the skull to the hallux. The role of osteotomy in the correction of deformity is under appreciated in part because of the ubiquitous nature of joint replacement surgery. It should be remembered, however, that osteotomy has a role to play in the correction of deformity in the growing child, the active young adult, and patients of any age with post-traumatic deformity limiting function and enjoyment of life. In this text we bring you a number of papers defining specific problems for which osteotomy is found to be an effective and lasting solution. I hope you find it useful.

\title{
How to reference
}

In order to correctly reference this scholarly work, feel free to copy and paste the following:

Salvatore Bisicchia and Eugenio Savarese (2012). Role of High Tibial Osteotomy in Chronic Posterior Cruciate Ligament and Posterolateral Corner Knee Instability, The Role of Osteotomy in the Correction of Congenital and Acquired Disorders of the Skeleton, Prof. James Waddell (Ed.), ISBN: 978-953-51-0495-7, InTech, Available from: http://www.intechopen.com/books/the-role-of-osteotomy-in-the-correction-of-congenital-andacquired-disorders-of-the-skeleton/role-of-high-tibial-osteotomy-in-chronic-posterior-cruciate-ligament-andposterolateral-corner-knee-

\section{INTECH}

open science | open minds

\section{InTech Europe}

University Campus STeP Ri

Slavka Krautzeka 83/A

51000 Rijeka, Croatia

Phone: +385 (51) 770447

Fax: +385 (51) 686166

www.intechopen.com

\section{InTech China}

Unit 405, Office Block, Hotel Equatorial Shanghai

No.65, Yan An Road (West), Shanghai, 200040, China

中国上海市延安西路65号上海国际贵都大饭店办公楼 405 单元

Phone: +86-21-62489820

Fax: +86-21-62489821 
(C) 2012 The Author(s). Licensee IntechOpen. This is an open access article distributed under the terms of the Creative Commons Attribution 3.0 License, which permits unrestricted use, distribution, and reproduction in any medium, provided the original work is properly cited. 